\title{
Tourist Object in Tomohon City as a Basic Consideration for Tourism Destination Development in Highland Ecosystem
}

\author{
Henny Johanna Kambey \\ Agricultural and Animal Husbandry Office of North Sulawesi, Manado, North Sulawesi, Indonesia
}

\begin{abstract}
Tourism potential attraction identification is the crucial aspect in tourism destination planning and development. Tomohon in North Sulawesi rich in term of tourism attraction, but tourism development is limited. Based on the tourism potential identification, Tomohon has numerous natural and potential attractions. The highland environments of Tomohon contributes significantly in natural tourism object. Tourism potential distributes in all area of Tomohon city with north Tomohon as centre of tourism destination. Natural resources of Tomohon should be managed in sustainable manner following sustainable principles.
\end{abstract}

Keywords: agrotourism, mountain tourism, sustainable tourism, tourism data.

\section{INTRODUCTION}

Tourism is becoming important in Indonesia. Tourism development in Indonesia can play a strategic role in national development and may be designated to provides new opportunities of jobs and reduce poverty. Tourism has the potential to create support for local economic development. The most important characteristic of Indonesia tourism product is the unique cultural and natural attractions. Indonesia archipelago is home is the numerous tropical biodiversity. Indonesia has numerous tribal communities with its unique traditional value and knowledge to manage natural resources. This has important consequences in tourism development $[1,2,3]$.

Most countries involved in tourism industry have some development planning, including compilation of basic data of natural and cultural tourism object. Tourism resources identification is the ultimate aspect to sustainable tourism destinations, especially in area where tourism and conservation occurs. Basically, information on the natural and cultural resources should be available in the first steps of tourism destination planning. A significant contribution of preliminary survey of tourism resources has been its benefits in planning process. Preliminary survey produces a variety of basic data that are important for destination planning and product development [4].

Tourism in North Sulawesi is important sector for regional development and environmental

\footnotetext{
* Correspondence address: Henny Johanna Kambey

Address : Jl. Raya Manado Tanawangko, Komplek Pertanian, Kalasey 95041, Manado.
}

conservation. Integrating tourism in cultural preservation and biodiversity conservation is important for tourism development in North Sulawesi. There is numerous tourism attraction in North Sulawesi which are important for local economic development. Tomohon city in North Sulawesi is one of the centre of tourism attraction $[5,6,7]$. According to statistical data, tourist grows significantly. Domestic tourist at 2010 was recorded about 23,832. Number of tourism in crease in 2011 (30,576 domestic tourist) and in 2012 (54,311 domestic tourist). In 2013, about 126,597 domestic tourist was recorded visit Tomohon. Number of international tourist was recorded about 3,954 in 2010 and 4,872 in 2011. These number increase about 5,434 in 2012 and 13,534 in 2013. The economic contribution of tourism was reported significant [8]. The statistical data of tourist arrivals shows that tourism sectors is one of the potential economic earning in Tomohon. Located at the highland environment, Tomohon offer spectacular landscapes which are crucial in tourism destination development. Highland landscapes is the driver of the tourism grows in Tomohon area and factors of the expansion of tourism accommodation development. The aims of the paper is to describes the potentiality of tourism object of Tomohon city in North Sulawesi.

\section{DIVERSITY OF POTENTIAL TOURIST ATTRACTION}

Tomohon city located at highland region in North Sulawesi province. Together with Lake Tondano, the area of Tomohon and Tondano has been declared as national strategic area for tourism development (locally KSPN TomohonTondano) (Fig.1). Geographically, Tomohon 
located at latitute $01^{\circ} 18^{\prime} 51^{\prime \prime}$ and longitude $124^{\circ} 49^{\prime} 40^{\prime \prime}$. Administratively, Tomohon city covers an area about $147.21 \mathrm{~km}^{2}$. The city located at 400-1500 asl with temperature ranges from $18^{\circ} \mathrm{C}$ to $30^{\circ} \mathrm{C}$. The rainfall was about 291.04 $\mathrm{mm} / \mathrm{month}$ and the average of humidity was recorded about $90.67 \%$ [8].

Tomohon area rich in term of tourism object. As far, some important tourism destination has been mentioned visited by tourist (Fig.2). These destinations are described below.

\section{Lake Linow}

Lake Linow is one of the potential lake for tourism activity in Tomohon city. Lake Linow has been considered as one of the unique lakes because the existence of active sulfur holes in the periphery of lake. Sulfur contributes significantly to the lake color which are visually very attractive and beautiful as tourism attraction. Lake Linow has been visited by both domestic and international tourist. Accessibility is consi-dered easy, and some tourist facility in lake Linow has established to enhance tourist satisfaction in lake Linow.

\section{Bukit Doa}

Bukit Doa, or Kelong Hill, Prayer Hill of Tomohon is one of the important sites for religious tourism in Tomohon. Kelong hills located at the slope of Mt. Mahawu with beautiful highland panorama. In some points along road to Bukit Doa there are special sites for religious tourism, including Chapel of Mother Mary, The Grotto of Mother Mary, Mahawu Cave and Amphitheater to facilitate religious-based activity. Bukit Doa is special religious sites among Christians community in North Sulawesi. Bukit
Doa is a religious tourist icon and religious tourist symbol for people in North Sulawesi.

\section{Mount Mahawu}

Mt. Mahawu is potential tourism desti-nation for mountaineering and special inte-rest tourism development. Mt. Mahawu is important habitat for numerous plant tree species such as Ficus celebensis, Pinanga sp, Sauraria minahasae, Pinanga caesia, and Pigafeta filiaris. This mountains is also habitat for animals such as wild boar and bird species, i.e. Scalybreast kingfisher and Mountain tailorbirds. There are also Crimson-crowned Flower peckers, Sooty-headed bulbuls and Grey-sided Flower peckers were found in Mt. Mahawu [9]. Mt. Mahawu is important habitat for numerous biodiversity, and therefore tourism program and development in Mt. Mahawu should be designed following sustainable tourism principles.

\section{Rurukan}

Rurukan is very famous village with spectacular highland panorama. Highland environment offer spectacular panorama and cool climates which are preferred by tourist. There are agrotourism program in Rurukan. Flower and vegetables are the important instrument of tourism attraction in Rurukan villages.

Tomohon flower festival is one of the important tourism events in Sulawesi. The local government of Tomohon very active to promotes Tomohon as tourism destination. Every August, there are special events called Tomohon Flower Festival which area implemented as a tourism attraction and promotion.

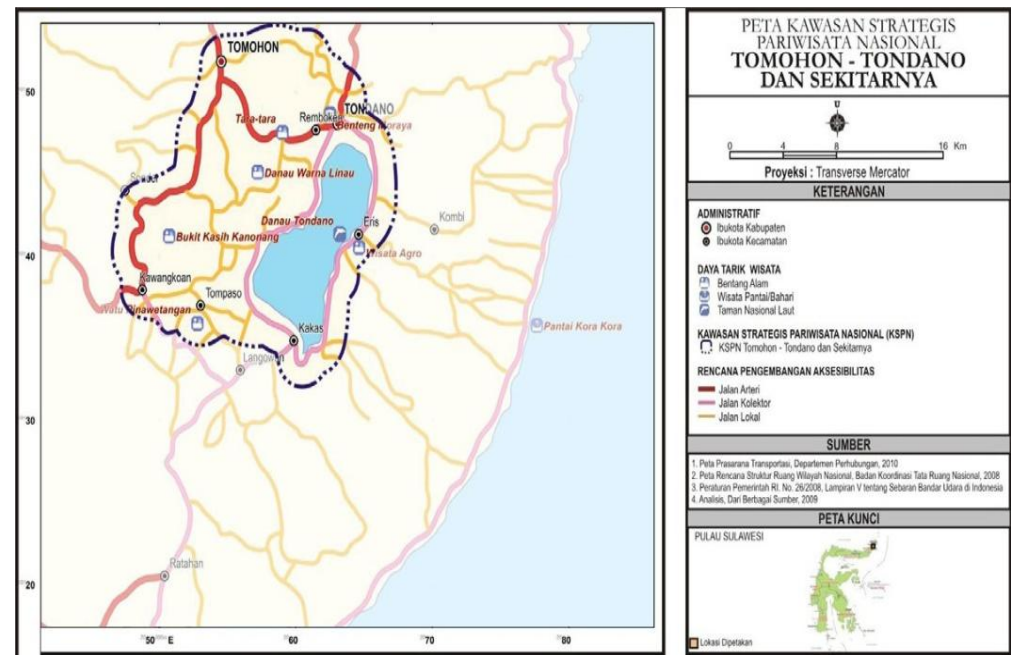

Figure 1. The Geographic Position of National Strategic Area for Tourism Development of Tomohon-Tonado (KSPN Tomohon-Tondano) 

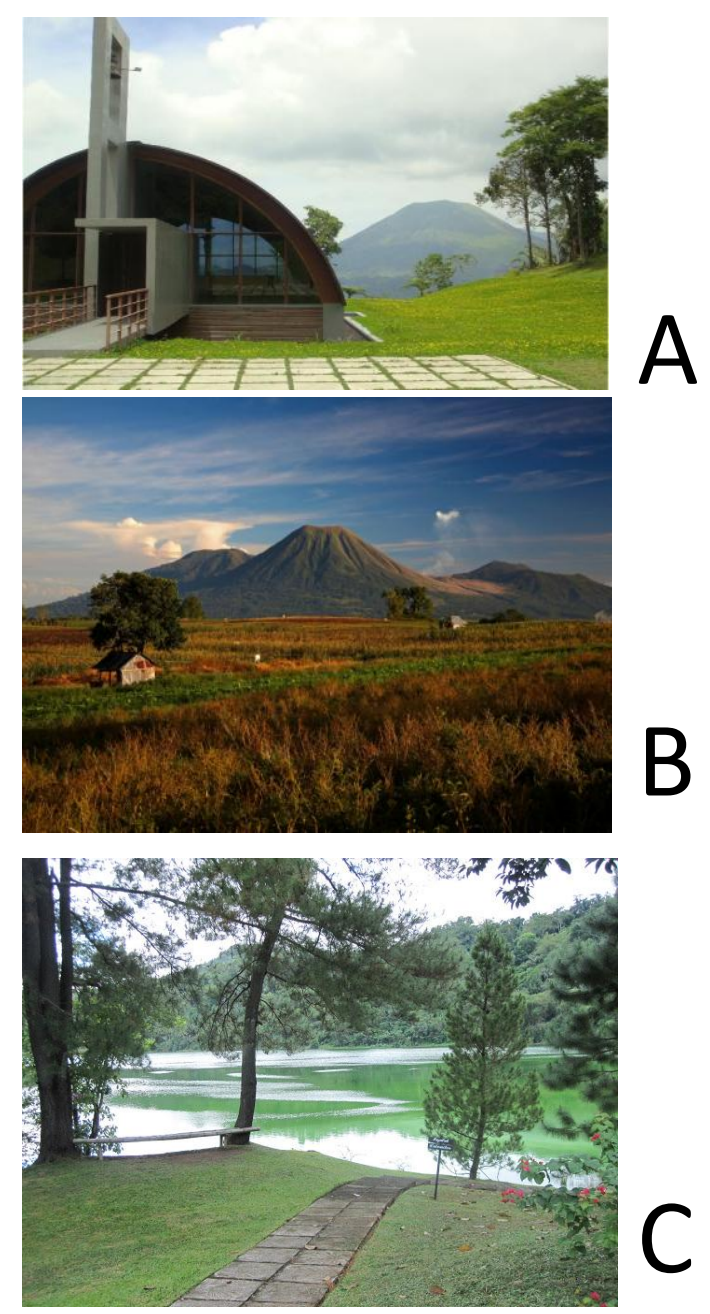

Figure 2. Some Natural Tourist Object in Tomohon. $A=$ Bukit Doa (www.indonesia-tourism.com) $\mathrm{B}=$ Wawo walian Hills (http://amazingtomohon.com) $\mathrm{C}=$ Lake Linow (anekanusantara.blogspot.com)

\section{SPATIAL DISTRIBUTION OF ATTRACTION}

Tourism potential object distributes in five regency of Tomohon, namely North Tomohon, South Tomohon, central Tomohon, East Tomohon, and West Tomohon (Table 1). North Tomohon has the highest number of tourism attraction, ranging from natural, cultural and religious tourism attractions.

There are however, some interesting villages for tourism development. Rural area of Tomohon city, namely Rurukan, Kakaskasen II, Kinilow, Pinaras and Lahendong that has been reported as potential sites for tourism. These areas varies in topography, ranging from flat to slopes lands. These area principally dominated by agricultural lands.

\section{Rurukan village}

Rurukan village located at East Tomohon sub district that has been known as the highland destination to enjoy mountains landscapes. In some point, visitors can see highland landscape with Mt. Mahawu, Temboan Hills and Tintingon peak. There are also panorama of the crater of Mt. Mahawu and Mt. Lokon. Bunaken islands easily observed from some sites in Rurukan Villages. Visitor also can see Lake Tondano with agricultural lands.

\section{Kinilow}

This village was known as centre of bamboo crafting. There are some tourist home-stay with standard facility and beautiful panorama. Kinilow village has potential beauty landscape for further tourism attraction development.

\section{Kakaskasen II}

Kakaskasen II villages administratively belong to North Tomohon sub district. This villages was known as flower village and sites for trekking to Mt. Lokon. Trek to Mt. Lokon can be said spectacular, with beautiful panorama. In agricultural lands, local people manipulate sloping upland. Rapid development of agriculture and the uses of chemical fertilizer in this area has been considered as one of the important aspect for unsustainable farming. There has been a major increase in the agricultural area with intensification farming.

\section{Pinaras}

Administratively, Pinaras Village belong to the South Tomohon sub district. There are numerous attraction in Pinaras villages, including hot water and water fall. The Pinaras water fall was estimated has $70 \mathrm{~m}$ in high, and the accessibility to the waterfall was easy. The distance of waterfall from Tomohon city was about $7 \mathrm{~km}$. This waterfall is one of the favourites tourist destination in Tomohon.

\section{Lahendomg Village}

Lahendomg villages belong to South Tomohon sub regency. There is numerous nature based attraction in Lahendong villages, including Lake Linow. There are pines plantations in Lahendong which is potential to develop as camping ground and other nature-based activity. 
Table 1. The Distribution of Natural and Cultural Attraction of Tourism in Tomohon

\begin{tabular}{|c|c|c|c|c|}
\hline NORTH TOMOHON & SOUTH TOMOHON & CENTRAL TOMOHON & EAST TOMOHON & WEST TOMOHON \\
\hline Nature & Nature & Cultural & Nature & Nature \\
\hline 1.Mt. Lokon & 1. Mt. Lokon & 1.Opo Tololiu statue & 1. Rurukan rural tourism & 1. Industri Rumah \\
\hline 2. Regesan water fall & 2. Lake Linow & 2. Wood craft industry & 2. Peak of Temboan - & Tradisional \\
\hline 3.Indraloka pool & 3. Pine forest & 3.Duct colonial & Rurukan & 2. Waruga-waruga \\
\hline 4.Lupa Lelah Hills & 4. Hot water pool & building monument & 3. Arboretum Mt. & 3. Amphitheater \\
\hline 5. Korompis & Lahendong & 4.Waruga & Masarang in Paslaten & 4. Walanda water \\
\hline Wewengkang botanic & 5. Lake Tampusu & & II and Rurukan & spring \\
\hline garden & 6. Tumimperas & Religious & 4. Susuripen Cave- & \\
\hline 6.Opo Worang & waterfall & 1. Sion church & Rurukan & Cultural \\
\hline Monument & 7. Wawo hils & 2. Hati Kudus church & 5. Mt. Mahawu, Rurukan & 1. Mahzani \\
\hline 7.Inspirasi hills & & & & 2. Maengket dance \\
\hline 8. Flower market & Religious & & Cultural & \\
\hline 9. Craft industry & $\begin{array}{l}\text { 1. Nurul Iman } \\
\text { mosque }\end{array}$ & & $\begin{array}{l}\text { 1. Beriman traditional } \\
\text { market }\end{array}$ & \\
\hline Religious & & & 2. Maengket dance & \\
\hline 1.Seminary Catholic "St. & Cultural & & & \\
\hline Fransiskus Xaverius" & 1. Maengket dance & & & \\
\hline 2.Pagoda & 2. Masarang Palm & & & \\
\hline 3.Vihara "Surya & sugar factory & & & \\
\hline Dharma" & 3. Bamboo music & & & \\
\hline 4.Vihara "Buddhayana" & 4. Waruga & & & \\
\hline \multicolumn{5}{|l|}{ 5. Bukit Doa Mahawu } \\
\hline \multicolumn{5}{|l|}{ Cultural } \\
\hline \multicolumn{5}{|l|}{ 1. Maengket dance } \\
\hline \multicolumn{5}{|l|}{ 2.Bamboo Music } \\
\hline \multicolumn{5}{|l|}{ 3.Mahzani } \\
\hline \multicolumn{5}{|l|}{ 4. Kadera stone } \\
\hline \multicolumn{5}{|l|}{ 5. Waruga } \\
\hline \multicolumn{5}{|l|}{ 6.Sumanti stone } \\
\hline \multicolumn{5}{|l|}{ 7.Tumotowa stone } \\
\hline 8.Pasuwengen stone & & & & \\
\hline
\end{tabular}

Another potential villages for tourism development is encompasses Tondangow Village with white hills as tourism attraction, Pangolombian with Lake Limaney as tourist attraction, Woloan with traditional woody building industry as tourism attractions, Kayawu and Taratara with wide paddy terrace landscapes as tourist attractions. As far, there are few development policy in such villages to become competitive and sustainable tourism development. In perspective of local economic development, there are potentialities for the potential attraction development which are able to meets local economic development strategies. Scholars point out that this aspect is important $[10,11]$.

\section{IMPLICATION FOR DESTINATION DEVELOPMENT}

Different object require different approach and models of development. The development of Tourism in Tomohon provides significant example for the harmonious development between economic and environmental conservation in highland environment. Located at highland environment, the development of natural resources for tourism should be done in sustainable manner. In the perspective of regional hydrological cycle, Tomohon is important for water resources catchment area for the lowland area, i.e. Manado city. Therefore, Tomohon is important ecosystem in regional hydrological process. Rapid land uses changes in Tomohon provide significant negative impact to regional water cycle. With the decreasing of vegetation in highland ecosystem through rapid settlement and agricultural development, considerable amount of water are potentially loss [12]. The spatial development of tourism in tomohon therefore needs he basic consideration of hydrological aspect.

It is recommended that the regional planner and local government should have a proper integrated management plan. Local government is responsible for planning the space and natural resources in sustainable manner. Natural tourism object can be very sensitive. Numerous flora and fauna and fragile species. In the recent years, an enormous amount of research and literature in tourism has been produced on the important 
issues of environmental management in tourism destinations. Maintaining and conserving biodiversity is considered important to the success of tourism industry. In North Sulawesi, the local governments usually has legal authority and management contributions over most recreation forest, lakes and fragile landscapes [6].

The second issues related to the tourism destination development in Tomohon are related to the local people. Tourism development in Tomohon should be able to provides new opportunities for jobs and other local economicbased activity. Scholars point out that tourism development should be able to provides positive impact to local community, both social and economical aspect. In many case, however, there are example of the ittle contribution of tourism to local community [11]. This is become significant point of local government of Tomohon to increase local people involvement in tourism destination management.

Sustainable tourism stresses the important of balance between economy, ecology and social aspect in tourism destination. In such a case, the integrated management is important to deliver actions towards sustainable development. Process of the development of each aspect are continual, integrated and holistic. Tourism stakeholders, especially businessman, typically vary in their belief, reasons and background to the tourism development. One important implication is the sustainable balance among economy, social and environments is related to the communication. Stakeholder in Tohohon city need to be involved in any stages of destination planning, development and monitoring. It is especially important in sustainable tourism destination management $[13,14,15]$.

\section{CONCLUSION}

Recent rapid global tourism sectors grows contributes to the rapid development of tourism in Tomohon area. Tomohon has abundance natural and cultural resources for tourism development. Tourism development may further result in environmental and social disturbance. Therefore, the development of tourism potential in Tomohon need the comprehensive research in the basic natural and cultural resources, the potential distribution in the context of spatial aspect, and the design to convert potential resources becoming actual tourist product.

\section{REFERENCES}

[1] Picard, M., M. F. Lanfant, J. B., Allcock and E. M. Bruner. 1995. Cultural heritage and tourist capital: cultural tourism in Bali. International tourism: identity and change, 44-66.

[2] Ross, S. and G. Wall. 1999. Evaluating ecotourism: the case of North Sulawesi, Indonesia. Tourism management 20(6), 673682.

[3] Cukier, J., R. Sharpley and D. J. Telfer. 2002. Tourism employment issues in developing countries: examples from Indonesia. Tourism and development: Concepts and Issues, 165-201.

[4] Inskeep, E. 1991. Tourism planning: an integrated and sustainable development approach. Van Nostrand Reinhold.

[5] DeVantier, L. and E. Turak. 2004. Managing marine tourism in Bunaken National Park and adjacent waters, North Sulawesi, Indonesia. Project Report of Natural Resources Management III and Program's Areas \& Agriculture Team. Jakarta.

[6] Hakim, L., M. Soemarno and S. K. Hong. 2012. Challenges for conserving biodiversity and developing sustainable island tourism in North Sulawesi Province, Indonesia. Journal of Ecology and Environment 35(2), 61-71.

[7] Pangemanan, A., L. H. Maryunani and B. Polii. 2012. Economic analysis of Bunaken Nasional Park ecotourism area based on the carrying capacity and visitation level. Asian Transactions on Basic and Applied Sciences, 2(2).

[8] BPS Tomohon. 2014. Tomohon dalam angka. Statistic Centre of Tomohon City. North Sulawesi.

[9] Butar Butar, R. R., L. Hakim and I. R. Sastrahidayat. 2015. Plants as flagship species in tourism destination: a case study at mount Mahawu Tomohon, North Sulawesi, Indonesia. International Journal of Conservation Science, 6(4).

[10] Neto, F. 2003. A new approach to sustainable tourism development: Moving beyond environmental protection. Natural Resources Forum 27(3), 212-222.

[11] Cawley, M. and D. A. Gillmor. 2008. Integrated rural tourism: concepts and practice. Annals of Tourism Research 35(2), 316-337.

[12] Van Wirdum, G. 1991. Vegetation and hydrology of floating rich-fens. Geert van Wirdum. 
[13] United Nations. 1979. Guidelines for rural centre planning. UN- Economic and social commission for Asia and the Pacific. New York.

[14] Spenceley, A. 2005. Nature-based tourism and environmental sustainability in South Africa. Journal of Sustainable Tourism 13(2), 136-170.

[15] Epler, B. 2007. Tourism, the economy, population growth, and conservation in Galapagos. Charles Darwin Foundation. 